\title{
ESTIMATION OF CARBON STORAGE IN WATER LETTUCE (Pistia stratiotes) AT FRESHWATER SWAMPS
}

\author{
${ }^{1}$ Nida Humaida, ${ }^{2}$ Krisdianto, ${ }^{3}$ Setia Budi Peran \\ ${ }^{1}$ Graduate Program of Natural Resources and Environmental Management \\ Bogor Agricultural University, Bogor, West Java \\ Email: nidahumaida@yahoo.co.id \\ ${ }^{2}$ Department of Biology, Faculty of Matematics and Natural Sciences \\ ${ }^{3}$ Faculty of Forestry \\ Lambung Mangkurat University, Banjarbaru, South Kalimantan
}

\begin{abstract}
This study was conducted in Banjar Regency, in the areas of Keraton, Keramat Baru, Tungkaran, Akar Baru and Sungai Tabuk villages, South Kalimantan, from April-July 2009. The purpose of the study was to estimate the amount of carbon storage in water lettuce (Pistia stratiotes) at freshwater swamps. The information obtained through this study is expected to provide benefits for the swampland management. The swamplands observed were the ones with water lettuce growing in the swamps. The sampling was carried out using purposive sampling technique with the consideration of grouping water lettuce's distribution. The carbon storage measurement was performed by measuring biomass, organic carbon percentage in water lettuce, and total carbon storage in $\mathrm{m}^{2}$. The organic carbon was analyzed using Walkey \& Black's Method. There were also analyses of crude fiber and ash in water lettuce. Data were then analyzed using descriptive statistics and hierarchical clusters. The carbon storage in water lettuce at freshwater swamps in Banjar Regency ranged between $64.07-237.75 \mathrm{~g} / \mathrm{m}^{2}$. The average crude fiber ranged between $19.89-24.94 \%$ and ash between $20.91-28.69 \%$.
\end{abstract}

Keywords: carbon, lettuce, pistia, storage, swamp

\section{INTRODUCTION}

Currently, the increase in $\mathrm{CO}_{2}$ in the atmosphere due to the use of fuels from fossil biomass has caused global warming. There should be some efforts to take in order to reduce greenhouse gases, especially $\mathrm{CO}_{2}$, such as reducing carbon emissions.
The efforts to reduce greenhouse gases in the atmosphere, especially $\mathrm{CO}_{2}$, not only by reducing emissions but also by increasing the absorption of greenhouse gases. The existence of plants as a carbon sink in the atmosphere reduces $\mathrm{CO}_{2}$ (Bouwman, 1990). Through photosynthesis, $\mathrm{CO}_{2}$ is absorbed and converted by plants into organic carbon in the form of biomass. Absolute carbon content in biomass or the amount of carbon stored in biomass is known as carbon storage or carbon deposit (Apps et al., 2003).

Wetland is the largest carbon reservoir. Although it is only $4 \%$ of the surface area of the earth, it saves almost $33 \%$ of the total soil organic material on earth. Wetland is anaerobic and it is a good area to store carbon (Batten, 2008). Wetlands in Indonesia cover 38 million hectares or $21 \%$ of its lands, and Indonesia is the country with the largest wetlands in Asia (Basuki et al., 2004). According to Purwanto (2006), about 33.4 million hectares of the total Indonesian wetlands is swamplands and $36 \%$ of the total swamplands is in Kalimantan (Basuki et al., 2004).

The vegetation in swamplands is quite diverse and able to adapt to anaerobic and waterlogged areas either seasonal or permanent. The identification results of Budiman et al. (1988) in Jumberi et al. (2005) showed that there were 181 weed species from 125 genera in 51 families consisting of 110 species of broadleaf group, 40 species of grass group and 31 species of jigsaw group.

Water lettuce (Pistia stratiotes) is a broadleaf plant that floats and has an advantage in photosynthesis, providing oxygen and sunlight absorption (Marianto, 2002). According to Sukman and Yakup (1991), water lettuce has a high germination, rapid growth, 
great level of absorption or uptake of nutrients and water and high adaptability to the climate.

The high biomass provides an indication that the vegetation has a good potential to absorb carbon. According to Asdak (2002), the process of carbon absorption would be more optimal in newly grown plants or crops with a rapid growth. Water lettuce is one of the plants with the rapid growth found in freshwater swamps. This is interesting for the authors to evaluate the potential of carbon stored in water lettuce at freshwater swamp ecosystem so that the carbon stored per area need to be measured, as well as the crude fiber content and ash in each individual water lettuce.

\section{MATERIALS AND METHODS}

This research was conducted for four months from April to July 2009. The location of study was in Banjar regency, South Kalimantan, namely in the swamplands of Keraton, Keramat Baru, Tungkaran, Akar Baru, and Sungai Tabuk villages. The swamplands studied were the lands overgrown by water lettuce.

Sampling methods. The stations and the plots were purposively determined by considering the distribution of grouping water lettuces, the easily accessible location, the presence of plants used, and the ease in the sampling process. The layout of stations (sampling sites) was recorded based on the position indicated by Global Positioning System (GPS). The number of stations that had been set was 7 (seven). The sample plot of $1 \times 1 \mathrm{~m}^{2}$ was repeated 3 times. The number of individuals of each plot was calculated by the method of the smallest plots with an area of 25 $x 25 \mathrm{~cm}$. Total individuals in the plot were multiplied by 16 to obtain the total individual per $\mathrm{m}^{2}$. Ten samples of water lettuces were taken from each plot to measure the leaf length and fresh weight. Fresh weight was obtained by weighing the water lettuce leaves before being dried. The leaf length was measured to describe the fresh weight capacity of water lettuce.

Biomass measurement. The plant was cut into sections and then wrapped in paper and put in the oven at $80^{\circ} \mathrm{C}$ for approximately 48 hours to get the dry weight. Water lettuce which had been put into oven was weighed again to obtain a constant dry weight, and measured for the total biomass per $1 \mathrm{~m}^{2}$ by multiplying the dry weight of individual water lettuce with total individuals per $\mathrm{m}^{2}$.

Carbon Measurement. The sample of dried water lettuce was weighed (approximately $0.05 \mathrm{~g}$ ), and was then added into $100 \mathrm{~mL}$ volumetric flask and added with $10 \mathrm{~mL}$ of $\mathrm{K}_{2} \mathrm{Cr}_{2} \mathrm{O}_{7} 1 \mathrm{~N}$ and concentrated $\mathrm{H}_{2} \mathrm{SO}_{4}$. The solution was shaken on rather wet and soft flannel cloth for 10 minutes. If its color was still green, more solution of $\mathrm{K}_{2} \mathrm{Cr}_{2} \mathrm{O}_{7}$ and concentrated $\mathrm{H}_{2} \mathrm{SO}_{4}$ was added and the addition was recorded. The solution was then let to cool down before being passed with distilled water and shaken again, and let alone for 24 hours. The clear liquid was pipetted for $10 \mathrm{~mL}$ and filled in a $50 \mathrm{~mL}$ Erlenmeyer, added with $1 \mathrm{~mL}$ of concentrated $\mathrm{H}_{3} \mathrm{PO}_{4}$ and 2-3 drops of diphenil amine indicator. Next, the solution was titrated with standard solution of $\mathrm{FeSO}_{4} .7 \mathrm{H}_{2} \mathrm{O}$ as well as the blanko.

$$
\text { Organiic Carbon }(\%)=\frac{(\text { Blank }- \text { Sample }) \times 0.2 \mathrm{~N} \mathrm{Fe}_{2} \mathrm{SO}_{4}}{\text { Dry Weight }(g)} \times \frac{100}{10} \times \frac{12}{4} \times \frac{100}{77} \times 100 \%
$$

Carbon storage was obtained by multiplying the percentage of carbon in individual water lettuce by the total water lettuce biomass in freshwater swamps.

Crude Fiber Measurement. Water lettuce was dried in an oven and weighed as much as $2 \mathrm{~g}$, and put in a $500-\mathrm{ml}$ size Erlenmeyer, $50 \mathrm{~mL}$ of $1.25 \% \mathrm{H}_{2} \mathrm{SO}_{4}$ solution was added and boiled for \pm 30 minutes using an upright cooler. $50 \mathrm{~mL}$ of $3.25 \% \mathrm{NaOH}$ was added to the Erlenmeyer and boiled again for \pm 30 . When it was still hot, it was filtered with Bucher funnel containing non-ash filter paper Whatman 42 which had been dried and weighed. The precipitate on filter paper was successively washed with the solution of hot water until the $\mathrm{pH}$ became neutral, $\mathrm{K}_{2} \mathrm{SO}_{4}$, and $96 \%$ ethanol. Filter paper and its content were removed and put in a scale that had been weighed, dried in $105^{\circ} \mathrm{C}$, and let it cool. The weighing was performed until the weight became constant. When the crude fiber was $\geq$ $1 \%$, the filter paper as well as its content was made into ash and weighed until the weight got constant.

$$
\begin{gathered}
\text { Crude fiber }(\%)=\frac{w-\left(w_{1}+w_{2}\right)}{\text { sample }} \\
\mathrm{W}=\underset{\text { (g) }}{\text { weight of filter paper }+ \text { content }+(\mathrm{g})+\text { cup }}
\end{gathered}
$$


$\mathrm{W}_{1}=$ weight of ash $(\mathrm{g})$

$\mathrm{W}_{2}=$ weight of filter paper $(\mathrm{g})$

Ash Content Measurement. Ashing cup was prepared. It was burnt in a furnace and cooled in a desiccator. After it was cool, the cup is weighed. Water lettuce sample was weighed as much as $3-5 \mathrm{~g}$ in the cup. The cup containing the sample was inserted into the ashing furnace and burnt to be gray ash or until its weight was constant. The ashing process was carried out in two stages, first at a temperature of around $400^{\circ} \mathrm{C}$ and the second at a temperature of $550^{\circ} \mathrm{C}$. The cup was cooled down in a desiccator and weighed to obtain the weight of the ash.

Measurement of Environmental Parameters. Soil sampling for each location would be carried out at three different points using a ground drill, and the soil was then wind dried for 48 hours. The sampling was done only once at each station. The $\mathrm{pH}$ of the soil and water was measured in a laboratory. The analysis of soil chemical included the analysis of total $\mathrm{N}$ with Kjedahl method, total $\mathrm{P}(\mathrm{HCl} 25 \%$ extract), and total $\mathrm{K}$ with AAS method (Atomic Absorption Spectrophotometer).

Methods of collecting data. The collection of primary data was in the forms of analysis data of organic carbon content, crude fiber, and ash in water lettuce, the results of samples from the field. The supporting data was in the forms of rainfall and dry season data from BMKG Banjarbaru.

Analysis methods. Data were presented in tabulation and analyzed descriptively and in hierarchical cluster way to show the relationship of data at each station.

\section{RESULTS AND DISCUSSION}

\section{Carbon Storage Measurement}

$\mathrm{CO}_{2}$ is absorbed through photosynthesis with the help of sunlight and converted by plants into organic carbon in the form of biomass (Apps et al. 2003). Biomass includes all plant material which roughly comes from the results of photosynthesis, nutrient uptake, and water treated through the process of biosynthesis (Sitompul \& Guritno 1995). Water lettuce (Pistia stratiotes) is broadleaf plant and grows in big groups which has an advantage as $\mathrm{CO}_{2}$ storage agent. It is spread pretty widely at freshwater swamps in Banjar Regency, South Kalimantan. Water Lettuce's leaf length frequency and fresh weight frequency are showed in Table 1 and Table 2.

Table 1. Leaf length frequency of water lettuce at each station

\begin{tabular}{ccccccccccr}
\hline $\begin{array}{c}\text { Class } \\
(\mathbf{c m})\end{array}$ & Keraton & $\begin{array}{c}\text { Keramat } \\
\text { baru 1 }\end{array}$ & $\begin{array}{c}\text { Keramat } \\
\text { baru 2 }\end{array}$ & $\begin{array}{c}\text { Tungka- } \\
\text { ran 1 }\end{array}$ & $\begin{array}{c}\text { Tungka- } \\
\text { ran 2 }\end{array}$ & $\begin{array}{c}\text { Akar } \\
\text { Baru }\end{array}$ & $\begin{array}{c}\text { Sungai } \\
\text { Tabuk }\end{array}$ & Total & $\begin{array}{c}\text { Total } \\
\%\end{array}$ \\
\hline \hline $2,6-3,5$ & - & 11 & - & 2 & - & - & - & 13 & 6,19 \\
$3,6-4,5$ & - & 18 & 12 & 9 & 4 & - & 1 & 44 & 20,95 \\
$4,6-5,5$ & - & 1 & 17 & 15 & 6 & 2 & 8 & 49 & 23,33 \\
$5,6-6,5$ & 5 & - & 1 & 4 & 13 & 8 & 14 & 45 & 21,43 \\
$6,6-7,5$ & 5 & - & - & - & 3 & 10 & 4 & 22 & 10,48 \\
$7,6-8,5$ & 4 & - & - & - & 4 & 4 & - & 12 & 5,71 \\
$8,6-9,5$ & 6 & - & - & - & - & 3 & 3 & 12 & 5,71 \\
$9,6-10,5$ & 3 & - & - & - & - & 2 & - & 5 & 2,38 \\
$10,6-11,5$ & 1 & - & - & - & - & 1 & - & 2 & 0,95 \\
$11,6-12,5$ & 4 & - & - & - & - & - & - & 4 & 1,90 \\
$12,6-13,5$ & 2 & - & - & - & - & - & - & 2 & 0,95 \\
\hline Total & 30 & 30 & 30 & 30 & 30 & 30 & 30 & 210 & 100 \\
\hline
\end{tabular}


Nida Humaida, Krisdianto, Setia B. Peran: Estimation Of Carbon Storage In

Table 2. Fresh weight frequency of water lettuce at each station

\begin{tabular}{cccccccccc}
\hline Class (g) & $\begin{array}{c}\text { Keraton } \\
\end{array}$ & $\begin{array}{c}\text { Keramat } \\
\text { baru 1 }\end{array}$ & $\begin{array}{c}\text { Keramat } \\
\text { baru 2 }\end{array}$ & $\begin{array}{c}\text { Station } \\
\text { ran 1 }\end{array}$ & $\begin{array}{c}\text { Tungka- } \\
\text { ran 2 }\end{array}$ & $\begin{array}{c}\text { Akar } \\
\text { Baru }\end{array}$ & $\begin{array}{c}\text { Sungai } \\
\text { Tabuk }\end{array}$ & Total & $\begin{array}{c}\text { Total } \\
\text { \% }\end{array}$ \\
\hline \hline $0.01-5,00$ & - & 1 & - & - & - & - & - & 1 & 0,48 \\
$5,01-10,00$ & 2 & 8 & 16 & 10 & - & 1 & 10 & 47 & 22,38 \\
$10,01-15,00$ & 8 & 15 & 8 & 14 & 2 & 10 & 13 & 70 & 33,33 \\
$15,01-20,00$ & 4 & 5 & 5 & 5 & 11 & 9 & 4 & 43 & 20,48 \\
$20,01-25,00$ & 3 & - & 1 & 1 & 5 & 4 & 3 & 17 & 8,10 \\
$25,01-30,00$ & 6 & 1 & - & - & 6 & 2 & - & 15 & 7,14 \\
$30,01-35,00$ & 1 & - & - & - & 3 & 2 & - & 6 & 2,86 \\
$35,01-40,00$ & 1 & - & - & - & 2 & 1 & - & 4 & 1,90 \\
$40,01-45,00$ & 3 & - & - & - & 1 & 1 & - & 5 & 2,38 \\
$45,01-50,00$ & 2 & - & - & - & - & - & - & 2 & 0,95 \\
\hline Total & 30 & 30 & 30 & 30 & 30 & 30 & 30 & 210 & 100 \\
\hline
\end{tabular}

Notes:
1. Keraton
2. Keramat Baru 1
5. Tungkaran 2
3. Keramat Baru 2
6. Akar Baru
4. Tungkaran 1
7.SungaiTabuk

The value of biomass was obtained from multiplying the average dry weight of the individual water lettuce by the average number

of individuals per $\mathrm{m}^{2}$ at each sampling station. The water lettuce biomass at each station was presented in graphs in Figure 1 below.

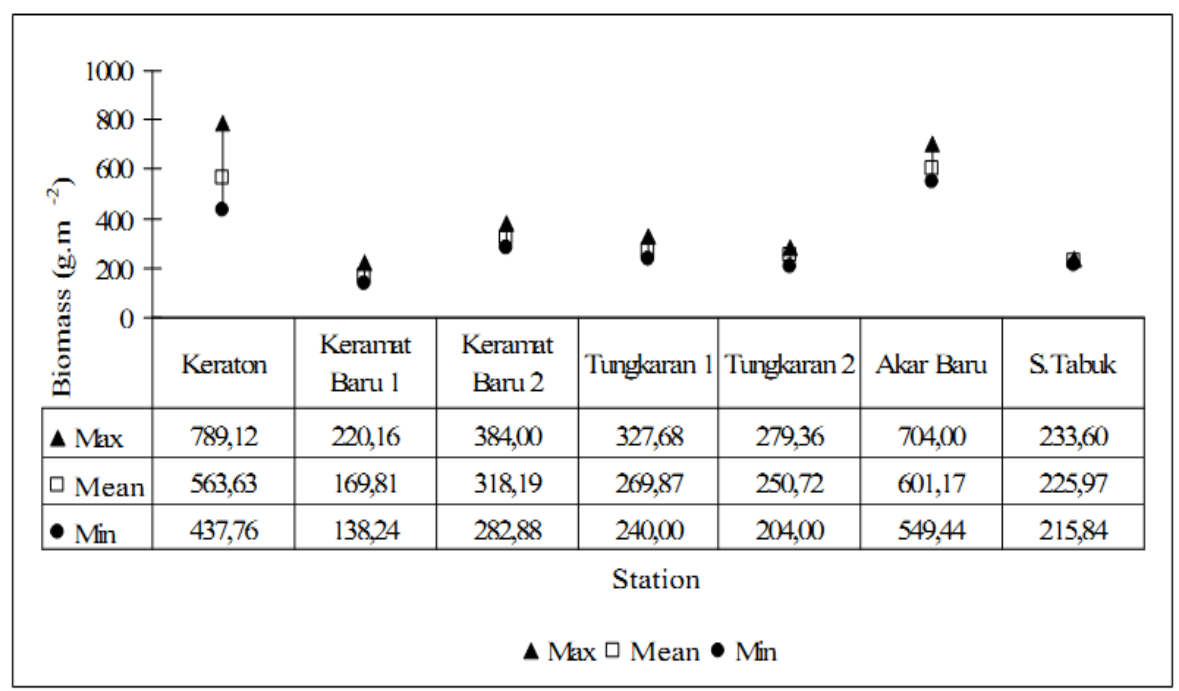

Figure 1 Biomass of water lettuce (Pistia stratiotes) at each station

Figure 1 shows that the average water lettuce biomass ranged from 169.81 - 601.17 g. $\mathrm{m}^{-2}$ with the highest biomass at Akar Baru station and the lowest at Keramat Baru station 1. In his research, Tucker (1983) stated that the optimum water lettuce biomass was about 200 g. $\mathrm{m}^{-2}$, greater than the duck weed (Lemna minor L.) biomass which was about $20 \mathrm{~g} . \mathrm{m}^{-2}$, but it was smaller than water hyacinth (Eichornia crassipes) 1000 g.m-2. It indicates 
that water lettuce in Banjar Regency's freshwater swamps is grown better because the amount of its biomass exceeded the optimum amount of water lettuce biomass in general.

The range of leaf length and fresh weight of water lettuce at Keraton station and Akar
Baru was larger than the five other stations (Tables 1 and 2), and hence it had greater biomass. The longer the water lettuce leaves, the greater the fresh weight. It can also be proved by the linear relationship between the fresh weight and leaf length in Figure 2.

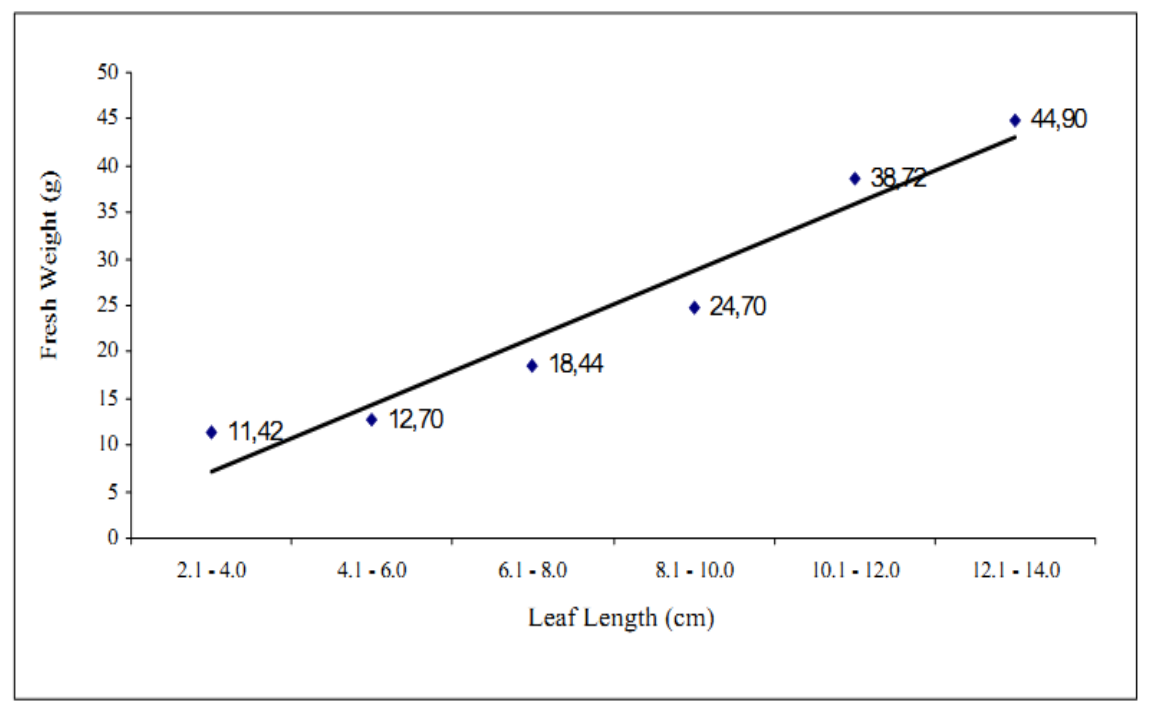

Figure 2. Average fresh weight of water lettuce (Pistia stratiotes) based on its leaf length from fresh water swamps in Banjar Regency

The process of carbon accumulation in the body of living plant is called Carbon sequestration. Plants take $\mathrm{CO}_{2}$ from the atmosphere and convert it into carbohydrates for growth. The amount of carbon that is absorbed and stored by plants is assumed to be proportional to the amount of organic carbon in it (Basuki et al, 2004). Thereby, measuring the amount of carbon stored in the body of living plants (biomass) in the landscape can describe the amount of $\mathrm{CO}_{2}$ in the atmosphere which is absorbed by the plant (Hairiah \& Rahayu 2007).

Results of laboratory analysis showed that the average percentage of carbon ranged from 32.73 to $41.49 \%$ with the highest average was at Keraton Station and the lowest at Akar Baru station. The percentage of organic $\mathrm{C}$ at each station was converted into the unit of g. $\mathrm{m}^{-}$ 2. When it was multiplied by the value of water lettuce biomass, the average value of carbon storage could be obtained, ranging from 64.07 - $237.75 \mathrm{~g}^{-2} \mathrm{~m}^{-2}$ with the highest amount at Keraton station and the lowest at Sungai Tabuk station. The complete result of total carbon storage in water lettuce at freshwater swamps in Banjar Regency is showed in Figure 3. 


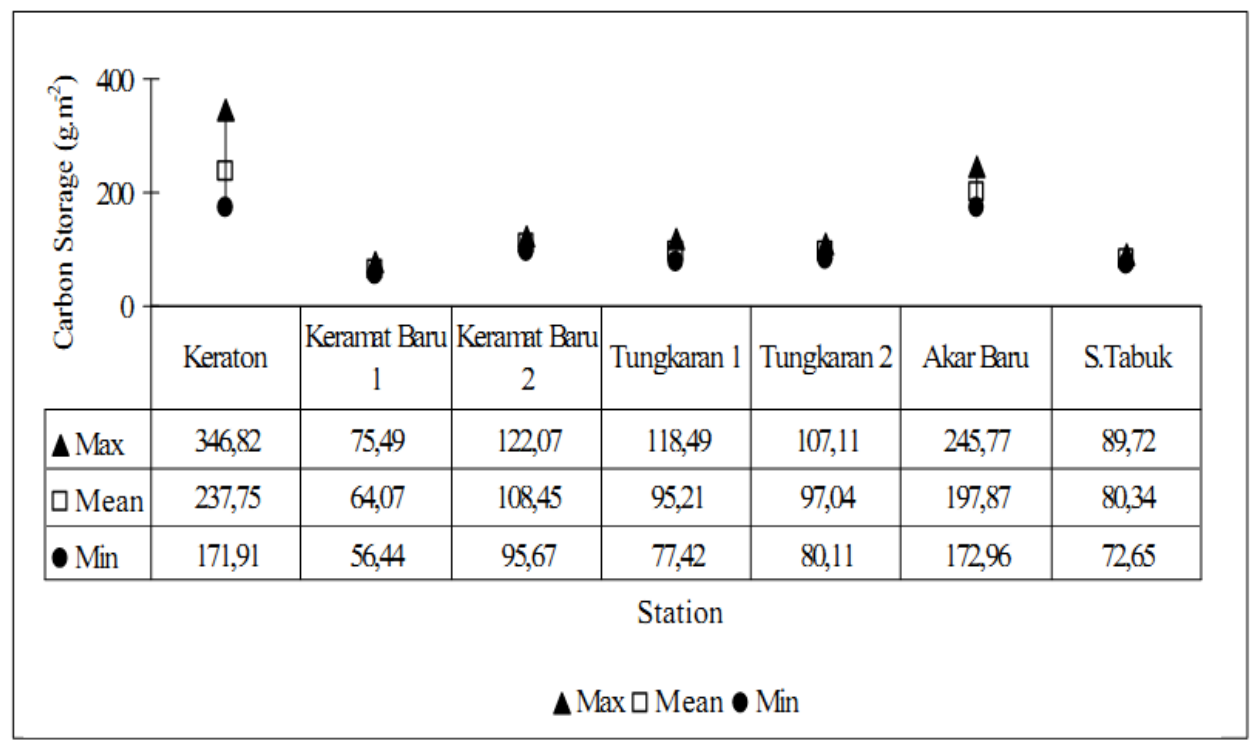

Figure 3 Total carbon storage in water lettuce (Pistia stratiotes) at each station

Hierarchical cluster analysis was conducted to show the relationship of data at each sampling station as showed in Figure 4.

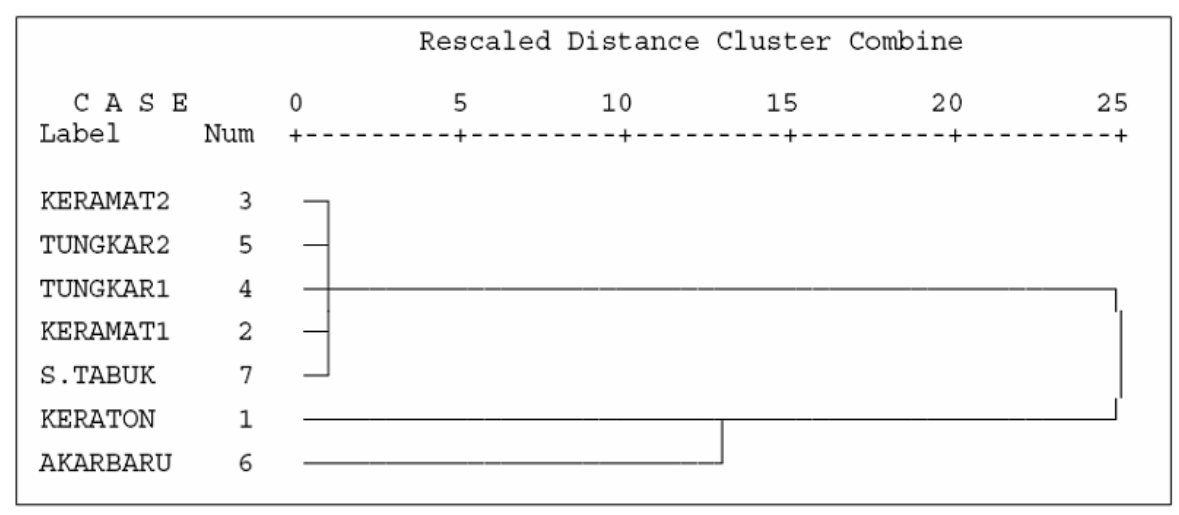

Figure 4. Cluster analysis of Carbon Storage in Water lettuce (Pistiastratiotes) from each station

Based on the results of the cluster analysis (Figure 4), there were two groups of stations that had similar amount of carbon storage. Group I was the carbon storage at Keramat Baru station 1, Keramat Baru 2, Tungkaran 1, Tungkaran 2, and Sungai Tabuk, and group II was that at Keraton Station and Akar Baru.
The amount of carbon storage among lands is different from each other, depending on the soil type and the way it is managed. The carbon storage in an area becomes higher when the fertility of soil is good (Hairiah \& Rahayu, 2007). Therefore, it was necessary to conduct environmental parameter measurement as showed in Table 3. 
Nida Humaida, Krisdianto, Setia B. Peran: Estimation Of Carbon Storage In

Table 3. Environmental parameter measurement results from each station

\begin{tabular}{lccccccc}
\hline \multicolumn{1}{c}{ Station } & $\begin{array}{c}\text { Average of } \\
\text { swamp depth } \\
(\mathrm{cm})\end{array}$ & $\begin{array}{c}\mathrm{pH} \\
\text { of } \\
\text { Water }\end{array}$ & $\begin{array}{c}\mathrm{pH} \\
\text { of } \\
\text { Soil }\end{array}$ & \multicolumn{3}{c}{ Soil Fertility } \\
\cline { 7 - 8 } Keraton & $\begin{array}{c}36,33 \\
\text { (Shallow) }\end{array}$ & 6,22 & 5,53 & 0,29 & 1,66 & 0,07 \\
Keramat Baru 1 & $\begin{array}{c}70,67 \\
\text { (Medium) }\end{array}$ & 5,93 & 5,01 & 0,14 & 0,23 & 0,05 \\
Keramat Baru 2 & $\begin{array}{c}70,33 \\
\text { (Medium) }\end{array}$ & 5,99 & 5,03 & 0,14 & 0,23 & 0,05 \\
Tungkaran 1 & $\begin{array}{c}48,00 \\
\text { (Shallow) }\end{array}$ & 6,19 & 4,93 & 0,44 & 0,84 & 0,08 \\
Tungkaran 2 & $\begin{array}{c}55,00 \\
\text { (Medium) }\end{array}$ & 6,28 & 4,93 & 0,44 & 0,84 & 0,08 \\
Akar Baru & $\begin{array}{c}19,00 \\
\text { (Shallow) }\end{array}$ & 6,31 & 5,12 & 0,14 & 0,56 & 0,12 \\
Sungai Tabuk & $\begin{array}{c}35,67 \\
\text { (Shallow) }\end{array}$ & 6,00 & 5,35 & 0,13 & 0,10 & 0,04 \\
\hline
\end{tabular}

\begin{tabular}{lcclll}
\hline Total N & Total K & Total P & Concentration & Scale & $\mathrm{pH}$ \\
\hline$<0.1$ & $<0.1$ & $<10$ & very low & $4.5-5.5$ & strong acid \\
$0.1-0.2$ & $0.1-0.2$ & $10-20$ & low & $5.6-6.5$ & weak acid \\
$0.21-0.5$ & $0.3-0.5$ & $21-40$ & medium & $6.6-7.5$ & neutral \\
$0.51-0.75$ & $0.6-1$ & $41-60$ & high & $7.6-8.5$ & low alkali \\
$>0.76$ & $>1$ & $>60$ & very high & $>8.6$ & high alkali \\
\hline
\end{tabular}

Table 3 shows that Keraton station had the higher value of $\mathrm{N}$ and $\mathrm{P}$ while at Akar Baru station contained higher $\mathrm{K}$ than other stations. Keraton station was an area which was near the rice fields not used by the local people, and so was Akar Baru station. In contrast to other stations such as Keramat Baru and Tungkaran Keramat, these areas were used as dry rice fields so that the use of pesticides destroyed the aquatic plants needed and could affect the amount of biomass. Sungai Tabuk station also had low carbon storage because Sungai Tabuk contained the lowest $\mathrm{N}, \mathrm{P}$, and $\mathrm{K}$.

When compared with land vegetation, the water lettuce biomass was smaller but the percentage of organic carbon in it was almost the same as that in inland plants (invasion vegetation), such as Melastoma, Saccharum, Chromolaena, Wedelia and Imperata, whose carbon was $35.63 \%$, $26.49 \%$, $37.55 \%$, 30.57, and $43.72 \%$, respectively (Handy et al., 2002). Water lettuce has a rapid growth and high density so it requires further study to see whether the productivity of water lettuce is able to be aligned with terrestrial vegetation as biomass storing carbon by harvesting it periodically.

Plants store carbon and release carbon. In handling the impact of global warming due to the increase in $\mathrm{CO}_{2}$, the efforts to maximize $\mathrm{CO}_{2}$ absorption by plant biomass and to reduce $\mathrm{CO}_{2}$ emissions cannot be separated from the role of the carbon cycle. The process of decomposition in wetlands is slower than in the lands so the potential for storing carbon is bigger than the potential for emitting carbon. In relation to the carbon storage, the use of plants to produce other products serves to extend the plant's carbon cycle prior to decomposing and emitting carbon into the atmosphere.

\section{Water Lettuce's Potential}

Crude fiber of plants can be used as animal feed, fertilizer and paper material. Water lettuce in South Kalimantan in particular is seen as wild plant or weed. By knowing the fiber content in the water lettuce, it can be used as the information in determining the composition of animal feed so Water lettuce is no longer seen as useless weed. Therefore, in this study 
the crude fiber content in water lettuce was also calculated, which ranged between 19.89 $24.94 \%$ with the highest rate at Keramat Baru station 2 and the lowest at Sungai Tabuk station.

This result is similar to that of the research by Sridhar et al. (1982) in Lake Oba Nigeria, suggesting that water lettuce crude fiber was $21.9 \%$. These results are higher than that in Fonkou et al. (2002), water lettuce crude fiber was 15:14 \pm 6:37\% in Cameroon domestic waste. According to Allenby (1981), this plant thrived in water rich in nitrogen. When it was viewed from the $\mathrm{N}$ level of the soil in the studied freshwater swamp, the $\mathrm{N}$ content ranged from 0.13 to $0.44 \%$ and water lettuce thrived at higher $\mathrm{N}$ level. The water lettuce crude fiber content was influenced by soil fertility, one of which was $\mathrm{N}$ level.

Vascular water plants absorb, translocate, metabolize, and concentrate various chemicals. Pistia stratiotes can be used as bioremoval pollutant, change the level of dissolved oxygen, be used as the additional food supplement for pigs (Sridhar, 1986). In India, the ash of Pistia stratiotes is used for traditional medicine because Pistia stratiotes is saline and has high enough ash content. This plant has the ability to move minerals from water as well as indirectly oxidize dissolved organic materials. Ash from Pistia stratiotes contains potassium chloride, potassium sulfate, potassium carbonate, sodium carbonate, calcium sulphate, magnesium sulphate, iron oxide and alumina, some sand and silica (Warden, 2008).

The measurement of ash content was to determine the amount of minerals that could be absorbed by water lettuce. Laboratory analysis for ash content in water lettuce showed that the average percentage of water lettuce ash ranged from 20.91 to $28.69 \%$ with the highest rate at Akar Baru station and the lowest at Keramat Baru 2 station. These results were higher than those in Fonkou et al. (2002) that found out the water lettuce ash content was about $19.72 \pm 1.81 \%$ in Cameroon domestic waste. However, Sridhar et al. (1982) showed different results in Lake Oba, that the water lettuce ash content was about $30.1 \%$. It shows that the ash content in Pistia stratiotes would likely show variations in different types of waters, which means that the amount of minerals absorbed by water lettuce depends on the mineral content in its habitat.
After finding out that water lettuce was able to absorb minerals up to $20.91-28.69 \%$ of its dry weight, it can be said that this plant has the potential to absorb metallic minerals (pollutants). It is expected to add the water lettuce functionality for consideration in ecological evaluation of a swampland.

\section{CONCLUSION}

The amount of Water Lettuce's biomass in Banjar Regency's freshwater swamps exceeded the optimum amount of water lettuce biomass in general. Carbon storage in water lettuce (Pistia stratiotes) at freshwater swamps in Banjar Regency ranged from 64.07 - 237.75 g. $\mathrm{m}^{-2}$. The average percentage of water lettuce crude fiber ranged from 19.89 to $24.94 \%$, and the average percentage of water lettuce ash ranged from 20.91 to $28.69 \%$.

\section{REFERENCES}

Allenby, K.G. (1981). Some Analyses of Aquatic Plants and Their Waters. Hydrobiologica 77 : 177-189.

Apps, Canadell, M.J., Heimann, M., Jaramillo, V., Murdiyarso, D., Schimel, D. and Manning, M. (2003). Science Statement on Current Scientific Understanding of the Processes Affecting Terrestrial Carbon Stocks and Human Influences upon Them. IPCC. Geneva. pp.37.

Asdak, C. 2002. Hidrology and Watershed Management. Gadjah Mada University Press. Yogyakarta. pp. 440-517.

Basuki, T. M., Adi, R. N. and Sukresno (2004). Technical Information of Organic Carbon Stock in Pinus merkusii stand, Agathis loranthifolia stand and Soil. Proceedings Ekspose BP2TPDAS-IBB : 84-94. Surakarta.

Batten, K. 2008. Wetland Restoration Creating Green Jobs in the LowCarbon Economy. Obama-Biden Transition Project. USA. Retrieved Februari 2009 from http://change.gov/page/-/open\%20 government/yourseatatthetable/20090 108_Batten_Wtland.pdf. 
Bouwman, A. F. (1990). Soils and The Green House Effect. John Wiley and Sons. New York.

Fonkou, T., Agendia, P., Kengne, I., Akoa, A. and Nya, J. (2002). Potentials of Water Lettuce (Pistia stratiotes) in Domestic Sewage Treatment with Macrophytic Lagoon System in Cameroon. Proceedings of International Symposium on Environmental Pollution Control and Waste Management 7-10 January 2002, Tunis (EPCOWM' 2002): 709-714. Cameroon.

Hairiah, K and Rahayu, S. (2007). Estimation of Carbon Storage in Various Land uses. Bogor. World Agroforestry CentreICRAF, SEA Regional Office. Bogor. pp.77.

Handayani, I.P., Prawito, P. and Muktamar, Z. (2002). Post-Deforestation Land in Bengkulu, Sumatera: A Study on Role of Invasive Vegetation. Jurnal IImu-IImu Pertanian Indonesia 4.1 : 10 17.

Jumberi, Achmadi, Noor, M.and Mukhlis (2005). Diversity of Floral Resouces in Swamplands. Balai Penelitian Pertanian Lahan Rawa. Retrieved Februari 2009 from http://balittra.litbang.deptan. go.id/eksotik/Monograf\%20-1.pdf.

Marianto, L.A. (2002). Water Plants. Publisher Agro Media Pustaka. Jakarta.

Purwanto, S. (2006). Policies in Development of Freshwater swamps. Proceedings of National Seminar on Technology Inovation and Integrated Development of Freshwater swamps 2006. Directorate General of Food Crops. Departement of Agriculture. Banjarbaru.

Sitompul, S.M. and Guritno, B. (1995). Analysis of Plant growth. Universitas Gadjah Mada Press. Yogyakarta.

Sridhar, M.K.C, Sharma, B.M. and Ayodae, G.O. (1982). Trials of Pistia stratiotes L. as Animal Feed. Journal Aquatic Plant Manage. $20: 56-57$.

Sridhar, M.K.C. (1986). Trace element composition of Pistia stratiotes L. in a polluted lake in Nigeria. Hydrobiologia. 131: $273-276$.
Sukman, Y and Yakup (1991). Weeds and the Controlling Techniques. Publisher Ghalia Indonesia. Jakarta.

Tucker, C.S. (1983). Culture Densit and Productivity of Pistia stratiotes. Journal Aquatic Plant Manage 21 : 40-41.

Warden, C.J.H. (2008). Ash of Pistia Stratiotes:"Pans Salt". Chemistry of Vegetable Physiology and Agriculture. Retrieved June 2009 from http://www.rsc.org/delivery/_ArticleLink ing/DisplayArticleForFree.cfm?doi=CA 8834400819\&JournalCode $=$ CA. 